\title{
PARA ALÉM DAS REFORMAS MONETÁRIAS: CONTRIBUIÇÕES AO DEBATE SOBRE A CRISE DO ENCILHAMENTO
}

\author{
Lohana Monaco Bezerra ${ }^{1}$ \\ Victor Leonardo de Araújo² \\ Fernando Augusto Mansor de Mattos ${ }^{3}$
}

\begin{abstract}
Resumo: A análise realizada no presente trabalho tem início nos últimos anos do Império brasileiro e na transição para o regime republicano, com ênfase na primeira crise da República: o Encilhamento. O objetivo é questionar a visão monetarista presente na literatura sobre esse período, a qual defende que a crise brasileira teria sido provocada pelas reformas monetárias de ideologia papelista, isto é, por uma suposta má condução da política econômica. Esses anos são estudados com uma abordagem que busca causas externas para o Encilhamento, as quais tiveram origem na moratória argentina e na consequente crise do banco inglês Baring Brothers, eventos que afetaram fortemente a vulnerável periferia que compunha 0 sistema internacional do padrão ouro libra.
\end{abstract}

Palavras chave: Encilhamento. Ruy Barbosa. Baring Brothers. Padrão Ouro. Vulnerabilidade Externa.

\section{BEYOND MONETARY REFORMS: CONTRIBUTIONS TO THE DEBATE OF THE ENCILHAMENTO CRISIS}

Abstract: The analysis carried out in the present work begins in the last years of the Brazilian Empire and in the transition to the republican regime, with emphasis in the first crisis of the Republic: Encilhamento. The objective is to challenge the monetarist vision present in the literature about this period, which argues that the Brazilian crisis would have been caused by the monetary reforms of papelist ideology, that is to say, by a supposed mismanagement of the economic policy. These years are studied with an approach that seeks external causes for Encilhamento, originated in the Argentine moratorium and the consequent crisis of the English bank Baring Brothers, events that strongly affected the vulnerable periphery that composed the international system of gold standard.

Keywords: Encilhamento. Ruy Barbosa. Baring Brothers. Gold Standard. External Vulnerability.

\section{MÁS ALLÁ DE LAS REFORMAS MONETARIAS: CONTRIBUCIONES AL DEBATE SOBRE LA CRISIS DE ENCILHAMENTO}

Resumen: El análisis realizado en el presente trabajo comienza en los últimos años del Imperio brasileño y en la transición al régimen republicano, con énfasis en la primera crisis de la República: el Encilhamento. El objetivo es cuestionar la visión monetarista presente en la literatura sobre este período, que argumenta que la crisis brasileña habría sido causada por las reformas monetarias de una ideología papelista, es decir, por una supuesta mala conducta de la política económica. Estos años se han estudiado con un enfoque que busca causas externas para el Encilhamento, que se originó en la moratoria argentina y en la consiguiente crisis del

\footnotetext{
1Universidade Federal Fluminense, Departamento de Economia, Niterói, Brasil, lohanamonaco@hotmail.com, https://orcid.org/0000-0002-8811-4066.

2Universidade Federal Fluminense, Departamento de Economia, Niterói, Brasil, victoraraujo@id.uff.br, https://orcid.org/0000-0002-2320-5661.

3Universidade Federal Fluminense, Departamento de Economia, Niterói, Brasil, fermatt1@hotmail.com, https://orcid.org/0000-0002-1196-3246.
} 
banco inglés Baring Brothers, eventos que afectaron fuertemente a la periferia vulnerable que conformaba el sistema internacional del patrón oro.

Palabras clave: Encilhamento. Ruy Barbosa. Baring Brothers. Patrón Oro. Vulnerabilidad Externa.

\section{Introdução}

A transição do regime monárquico para a República foi marcada por uma série de reformas - dentre elas a conhecida reforma monetária de Ruy Barbosa -, as quais tiveram como objetivo, entre outros, a expansão da oferta de moeda e de crédito aos cafeicultores como forma de dar lastro a uma economia que, com o advento do trabalho assalariado, exigia uma expansão da oferta de meio circulante. Tais medidas foram estimuladas pelas constantes crises de liquidez que afetavam a economia, principalmente após a chegada em massa de imigrantes e a consequente disseminação do trabalho assalariado. Os programas de expansão monetária foram implementados num contexto de intensas discussões sobre câmbio e moeda que, não obstante datassem da metade do século XIX, aprofundaram-se a partir da década de 1880, em virtude dos efeitos econômicos (e monetários) da própria Abolição.

Segundo a abordagem tradicional, estariam nessas reformas as causas dos diversos problemas que pairaram sobre a economia na primeira década republicana, como a euforia no mercado acionário, o surgimento de "empresas fantasma" e a consequente falência de diversos bancos e estabelecimentos, bem como a aceleração da inflação, a desvalorização cambial e o colapso dos preços do café. O período de intensas turbulências no campo econômico, que teve início a partir do ano de 1891, ficou conhecido na literatura como Encilhamento. A visão ortodoxa sobre o tema sustenta que a espiral inflacionária e a instabilidade política gerada pela incerteza em relação ao novo regime teriam afugentado os investidores externos, provocando uma crise cambial de grandes proporções, a qual só foi superada na virada do século, com a adoção do programa ortodoxo do ministro Joaquim Murtinho.

No entanto, o presente trabalho busca associar a desvalorização da taxa de câmbio a fenômenos externos que exerceram forte influência sobre os ânimos dos agentes econômicos, o que oferecerá ao leitor uma interpretação alternativa para a crise do Encilhamento. O Brasil, em sua condição de país agroexportador, com alto coeficiente de importações e dependente da entrada de capitais estrangeiros, certamente não estava imune a efeitos severos de crises sistêmicas na conjuntura internacional do padrão ouro libra. Dada sua vulnerabilidade, por ser um país 
periférico inserido em um sistema notadamente assimétrico - em que pesem as enormes dificuldades que sofria a periferia que adotava a conversibilidade em ouro -, sofreu contágio de uma crise financeira que, em 1890, se originou em um país vizinho, a Argentina, e provocou a quebra de um dos mais sólidos e confiáveis bancos londrinos.

Para embasar a discussão que será introduzida mais adiante, a primeira seção analisa o cenário externo no qual estava inserido o Brasil no último quarto do século XIX: o sistema internacional do padrão ouro libra. A segunda seção expõe o debate entre metalistas e papelistas que se encontrava em curso no pais, para então serem analisadas, na seção seguinte, as medidas de expansão monetária adotadas nos últimos anos do Império e a reforma de Ruy Barbosa, logo após a instauração da República. A quarta seção exibe as causas e consequências do Encilhamento, segundo a visão ortodoxa. A quinta seção, por sua vez, introduz as transformações pelas quais passou a economia argentina no mesmo período, investigando as razões que levaram o país a declarar moratória em 1890 e estudando como esse evento afetou o banco inglês Baring Brothers. Por fim, a sexta seção trata dos canais de contágio dessa crise para o Brasil, apresentando uma visão alternativa para a crise do Encilhamento.

\section{O cenário externo no final do século XIX: a vulnerabilidade das economias periféricas na adesão ao padrão ouro}

O século XIX trouxe à Grã-Bretanha, juntamente com a Revolução Industrial, a emergência à condição de maior potência financeira e comercial do mundo. $A$ Inglaterra ingressou no padrão ouro em 1819, após o fim das guerras napoleônicas (EICHENGREEN, 2002). No entanto, a adoção do regime por uma série de países só veio a se consolidar a partir de $1870^{4}$. Na adoção do padrão ouro, cabia a cada país, individualmente, definir o preço de sua própria moeda em relação ao ouro, a uma taxa fixa. A sua moeda seria, portanto, lastreada em ouro, o que significava que sua oferta monetária estaria limitada pela quantidade de ouro em poder do seu banco central, e que toda sua política econômica deveria ser orientada a fim de garantir a conversibilidade.

Durante a segunda metade do século XIX e o início do século XX, o ingresso no padrão ouro foi considerado pelas correntes ortodoxas uma medida benéfica para

\footnotetext{
${ }^{4}$ Segundo Meneghetti (2006, p.15), o atraso de alguns países na adesão ao padrão ouro pode ser explicado pelo fato de que estes apresentavam bancos centrais em diferentes estágios de desenvolvimento.
} 
a economia, pois seria uma prova de "finanças sadias". A literatura convencional tem constantemente chamado a atenção para o fato de que as economias que aderiram ao padrão ouro apresentaram enorme estabilidade monetária e cambial. Embora muitos autores defendam sua contribuição no sentido de elevar a estabilidade macroeconômica na maior parte das economias centrais, o padrão ouro certamente não obteve o mesmo êxito na periferia.

Ao propor uma das primeiras reavaliações do padrão ouro ${ }^{5}$, Furtado (1959) tinha como principal objetivo demonstrar que a adesão a esse sistema causava inúmeros problemas aos países que o seguiam, especialmente se estes apresentassem uma estrutura produtiva e uma pauta exportadora pouco diversificadas, como era o caso da periferia. As economias periféricas encontrariam dificuldade na adesão ao padrão ouro por diversos motivos, como a tendência natural ao desequilíbrio externo e o caráter pró-cíclico desse sistema.

A tendência ao desequilíbrio externo decorria do fato de as economias periféricas serem geralmente especializadas na produção de um ou dois itens primários voltados à exportação - no Brasil, o café -, enquanto importavam uma grande variedade de produtos dos países do centro. A especialização em produtos primários, bem como as características climáticas sazonais e perecíveis desses produtos, tornava essas economias vulneráveis a quedas nos preços internacionais das commodities e à consequente deterioração dos termos de troca, em função da baixa elasticidade da demanda por bens primários. Destarte, diferenças nas estruturas produtivas dos países centrais e periféricos levavam estes a persistentes déficits em transações correntes, criando potencial para um recorrente desequilíbrio em seu balanço de pagamentos.

Um dos principais elementos que explicam a assimetria do padrão ouro reside no fato de que o comando da oferta dos financiamentos se encontra nos países centrais (Bastos, 2010). Para financiar os seus déficits, as economias periféricas precisavam recorrer a ajustes por meio da entrada de capitais, os quais estavam concentrados nos centros financeiros dos países centrais e, em períodos de crise internacional, os bancos ali sediados tendiam a se mostrar resistentes a pedidos de novos empréstimos. Assim, os crônicos déficits em transações correntes eram financiados somente em momentos de calmaria do cenário internacional. Também cabe destacar que, além de serem os mais prejudicados por uma eventual

\footnotetext{
${ }^{5}$ Segundo Bastos (2008), a visão de Furtado teve grande originalidade internacional, antecipando diversos argumentos revisionistas sobre as assimetrias do padrão ouro.
} 
interrupção dos fluxos de capitais, os países da periferia não tinham como controlar esses fluxos, ficando totalmente vulneráveis aos efeitos de crises externas, que eram mais habituais do que faziam crer os supostos mecanismos auto ajustáveis do padrão ouro.

O caráter pró-cíclico desse sistema, por sua vez, encontrava-se no fato de que as economias periféricas sofriam com a relação perversa entre sua conta capital e sua balança comercial, tendo como consequência constantes crises no balanço de pagamentos, que afetavam diretamente o comportamento da taxa de câmbio (FURTADO, 1959). Em períodos de crise, os déficits na conta corrente e na conta capital se reforçariam mutuamente. Quando ocorria uma queda nas receitas de exportação, por abalos nos preços das commodities no mercado internacional, os países da periferia sofriam para honrar seus compromissos externos. Diante da percepção desse fato por parte dos investidores, a entrada de capitais nesses países se reduzia drasticamente.

Dessa forma, Furtado (1959) defendeu que os desequilíbrios externos e a vulnerabilidade da periferia não poderiam ser atribuídos a políticas macroeconômicas não convencionais; na verdade, era a assimetria do sistema centro-periferia a raiz estrutural dos problemas monetários e cambiais pelos quais 0 Brasil passava. As economias periféricas que aderiam ao padrão ouro estavam condenadas a crises, já que necessitavam de capitais externos para financiar seus persistentes déficits no balanço de pagamentos.

Tendo em vista que as decisões de investimento localizavam-se nos países centrais, a periferia encontrava-se vulnerável a momentos de penúria no cenário internacional, nos quais a crise seria a ela transmitida pelo centro e reforçaria a relação perversa entre os déficits na conta corrente e na conta capital, bem como pioraria seus termos de intercâmbio e reduziria o volume de suas exportações. Como desvalorizar o câmbio não era uma opção para os países que adotavam a conversibilidade, o esforço recessivo necessário para sair da crise seria muito maior para a periferia, provocando enorme descontentamento social e, no limite, instabilidade política. No caso do Brasil, a instabilidade política era potencializada por problemas federativos e regionais, uma vez que os impostos que incidiam sobre as exportações eram destinados aos estados da federação (ou seja, na época da bonança, os estados exportadores de commodities eram os principais ou os únicos beneficiados), enquanto os impostos gravados sobre as importações caberiam à 
União, a qual, por sua vez, se incumbia de distribuir às unidades da federação mais pobres, o que ocasionava tensões políticas em época de crise.

\section{Discussões sobre câmbio e moeda: papelistas versus metalistas}

Com o surgimento do padrão ouro, correntes teóricas a favor e contra a conversibilidade começaram a surgir em diversos países. Apesar de ter adotado emissões lastreadas em ouro apenas por um curto período, o Brasil, estando inserido no padrão ouro libra, não ficou por fora da efervescência dessas discussões. Nesse sentido, pode-se afirmar que é a primeira década republicana (1890-1900) o período em que florescem os debates sobre câmbio e moeda em território brasileiro, mais especificamente entre as correntes papelistas e metalistas.

A discussão entre papelistas e metalistas data da metade do século XIX, ainda no Império - tendo como inspiração os debates britânicos entre bulionistas e antibulionistas e entre a Currency School e a Banking Schoof-, mas permaneceu e se aprofundou durante as primeiras décadas republicanas. A discussão centrou-se na conversibilidade da moeda, buscando pensar as políticas monetária e cambial no contexto de uma economia fundamentalmente agroexportadora. Os metalistas, de tradição mais ortodoxa, defenderam a adesão brasileira ao padrão ouro e preocuparam-se primordialmente com a estabilidade de preços, enquanto os papelistas, mais heterodoxos, criticaram a conversibilidade em ouro e demonstraram preocupação com os limites que o rígido funcionamento do padrão ouro impunha ao dinamismo da atividade econômica (FONSECA; MOLLO, 2012).

Os metalistas, de um lado, acreditavam que a emissão sem lastro em moeda estrangeira seria uma medida estéril que conduziria a economia à inflação, à especulação e à depreciação do câmbio, sem efeitos produtivos significativos. Nessa concepção, o remédio para as crises cambiais seria a retirada do excesso de

\footnotetext{
${ }^{6}$ Os debates bulionistas versus antibulionistas e Currency School versus Banking School datam do século XIX. O primeiro deles ocorreu entre 1797 e 1825 e tem o lado ortodoxo, dos bulionistas, representado principalmente por David Ricardo, enquanto o heterodoxo é defendido por nomes como Bosanquet e Torrens. Enquanto os bulionistas defendiam a Teoria Quantitativa da Moeda e a volta da conversibilidade em ouro como regra monetária capaz de controlar a emissão de moeda e o nível de preços, os antibulionistas rejeitavam a neutralidade da moeda e temiam esse tipo de controle, por acreditarem que provocaria uma inibição do crescimento e da acumulação de capital. Na segunda controvérsia inglesa, ocorrida entre 1825 e 1875, observa-se uma significativa mudança em relação à primeira: tanto os ortodoxos da Currency School como os heterodoxos da Banking School passam a defender a conversibilidade em ouro, divergindo em relação à necessidade de controles de curto prazo. (FONSECA; MOLLO, 2012).
} 
moeda inconversível de circulação, deflacionando preços e ativos e controlando o crédito e o gasto público com o objetivo de apreciar o mil-réis contra o ouro e a libra esterlina (BASTOS, 2008). Já os papelistas, rejeitando a neutralidade da moeda, defendiam que a expansão monetária possuía, de fato, a capacidade de afetar o nível de atividade econômica.

Enquanto os metalistas encontravam respaldo na teoria econômica convencional da época - já que suas ideias estavam consolidadas no pensamento clássico de grandes nomes como David Ricardo - e nas políticas econômicas seguidas pela Grã-Bretanha, os papelistas, "ante a ausência de um corpo teórico de mesma envergadura para defender o desapego ao que consideravam amarras às políticas monetárias e cambiais, recorriam à razão prática: a experiência, e não a teoria, demonstrava qual o melhor caminho a seguir". (FONSECA; MOLLO, 2012, p.215) As experiências mostravam as dificuldades de manter o padrão ouro e a plena conversibilidade, especialmente na periferia, sustentando 0 argumento papelista.

Os metalistas defenderam o controle da taxa de câmbio como fundamental para garantir a estabilidade de preços - o que implicava uma subordinação da política monetária à política cambial - e posicionaram-se a favor uma taxa de câmbio fixa no patamar apreciado de 27 pence $^{7}$ por mil réis ${ }^{8}$, enquanto os papelistas perguntavam-se qual seria o nível de oferta monetária compatível com um crescimento econômico razoável. Aos papelistas coube também o questionamento acerca das limitações presentes no receituário ortodoxo metalista, como a restrição à expansão da liquidez e o fato de a adesão ao padrão ouro tornar necessária, no caso de uma eventual crise de dimensões internacionais, um esforço recessivo muito maior - o que, de todo modo, nem sempre resolvia os problemas de balanço de pagamentos, que eram estruturais e não apenas conjunturais.

Os papelistas, por considerarem que a expansão monetária poderia ter efeito positivo sobre o emprego e na renda, defendiam um aumento da expansão monetária, ao menos em momentos de crises conjunturais. Alertavam sobre as crises constantes provocadas pela escassa oferta de moeda e, por esse motivo, defendiam a expansão do sistema bancário, de forma a pôr fim ao monopólio de emissão do Tesouro (LUNA; KLEIN, 2014). Medidas nesse sentido foram tomadas por notáveis papelistas, como Visconde de Ouro Preto e Ruy Barbosa, os quais

\footnotetext{
7 A libra, antes da reforma de 1971, era dividida em 20 shillings (que valiam 12 pence cada um) ou 240 pence.

8 Tal como a que fora adotada em 1846, na primeira tentativa brasileira de adesão ao padrão ouro.
} 
foram permanentemente apontados pela literatura ortodoxa como responsáveis pela instabilidade financeira verificada nos anos iniciais da República, conforme será visto adiante.

\section{As reformas monetárias que precederam o Encilhamento: de Saraiva a Ruy Barbosa}

Nos últimos anos do Império, o Brasil sofria com problemas de liquidez que já se faziam presentes desde a década de 1860 (FRANCO, 1983). A iminente abolição do trabalho escravo e a chegada em massa de imigrantes europeus elevou significativamente a população e criou uma necessidade extra de moeda para atender à demanda dessa mão de obra assalariada e garantir o pagamento de salários por parte dos cafeicultores. Além disso, o sistema bancário era pouco desenvolvido e havia grande propensão ao entesouramento, o que reduzia a capacidade de criação de crédito por parte dos bancos e dificultava sua concessão aos fazendeiros de café.

Somava-se a isso a prolongada seca do início dos anos 1890, que aumentou a demanda dos produtores por novos recursos líquidos (VILLELA; SUZIGAN, 1973). O monopólio de emissão do Tesouro, bem como a restrição monetária enfrentada nos anos anteriores, apenas agravara essa situação, levando a uma "oferta inadequada de moeda". (CALÓGERAS, 1960, p. 150). A década de 1880 foi o período da segunda metade do século XIX em que a política monetária brasileira mostrou-se mais restritiva. Dados de Botelho Jr. (2002) mostram que o meio circulante caiu de aproximadamente 216 mil contos de réis para 205 mil contos de réis em um espaço de oito anos. Dessa forma, a disseminação do trabalho assalariado veio a afetar o sistema bancário por meio de constantes crises de liquidez, com crescente gravidade à medida que se aproximava o ano da Abolição.

Nesse sentido, começou a se intensificar uma discussão acerca da necessidade de uma reforma monetária. O primeiro esforço realizado para resolver o problema de escassez de meio circulante foi a Lei de 18 de julho de 1885, do Conselheiro Saraiva, que autorizou o governo a emitir até 25 mil $\operatorname{contos}^{9}$, quantia que representava um acréscimo potencial de $20 \%$ sobre a base monetária (BOTELHO JR., 2002). No entanto, a medida não foi suficiente, mostrando-se eficaz apenas no curto prazo. Em seguida, surgiu o primeiro grande projeto de reforma, apresentado ao Senado em 1887, que originou a Lei de 24 de novembro de 1888.

\footnotetext{
${ }^{9} \mathrm{~A}$ expressão "um conto de réis" era designada para representar o equivalente a um milhão de réis.
} 
A Lei de 24 de novembro de 1888 foi posta em prática ainda no Império, seis meses após a Abolição, pelo Conselheiro João Alfredo de Oliveira, com o objetivo de resolver os problemas de liquidez e afagar os ânimos da oposição. Essa lei instituiu uma taxa de câmbio fixa e apreciada no patamar de 27 pence por mil réis, levando o país a ingressar, por um curto período, no padrão ouro. Porém, enquanto a lei buscava agradar aos metalistas por meio da adesão ao padrão ouro, ela procurava simultaneamente atender aos interesses papelistas via aumento da oferta monetária e do crédito. Possuía, portanto, um caráter naturalmente contraditório, buscando conciliar o inconciliável.

A "Lei Bancária de 1888", como ficou conhecida, autorizava a criação de bancos privados de emissão - o que significava o fim do monopólio do Tesouro -, os quais poderiam emitir tanto sobre lastro metálico como sobre títulos da dívida pública, além de prever ainda a contratação de um empréstimo de 100 mil contos para o financiamento da lavoura. Entretanto, devido às condições pouco vantajosas nas quais os bancos poderiam realizá-las ${ }^{10}$, na prática nenhum banco emitiu em lastro metálico ou sobre títulos da dívida.

Tendo em vista o fracasso da Lei Bancária de 1888 em relação à satisfação dos desejos da elite cafeicultora pós-Abolição e às expectativas gerais de um grande aumento da liquidez, bem como à deterioração do quadro político, a evidente fragilidade do governo imperial e a ascensão de movimentos republicanos, João Alfredo não resistiu à pressão e renunciou. Visconde de Ouro Preto assumiu a pasta da Fazenda em junho de 1889, anunciando como primeira medida a criação do Banco Nacional do Brasil ${ }^{11}$ (BNB), que teria poderes para controlar o câmbio e poderia emitir até 270 mil contos, quantia superior a todo o dinheiro em circulação (BOTELHO JR., 2002) A autorização para emissão de moeda, que antes era exclusivamente do Tesouro, foi expandida para mais três bancos: o Banco Nacional do Brasil (RJ), o Banco de São Paulo (SP) e o Banco do Comércio (RJ).

Em relação aos "auxílios à lavoura", talvez uma das principais apostas para conter o movimento republicano, Ouro Preto ampliou de forma significativa o sistema de crédito de João Alfredo, tendo o governo realizado despesas extraordinárias de

\footnotetext{
10 Pode-se citar o caráter contraditório da lei como um motivo importante que explicaria a ausência de emissões. Entretanto, havia ainda outras razões. No caso da emissão sobre lastro metálico, os riscos cambiais envolvidos na conversibilidade das notas desencorajavam os bancos. Já para a emissão sobre títulos da dívida pública, a falta de interesse pelas emissões era explicada simplesmente pela falta de lucratividade. Para mais detalhes, ver Schulz (1996) e Barbosa (2009).

11 O BNB foi criado em 16 de setembro de 1889, em reunião que consolidou a fusão do antigo Banco Nacional com o Banco Intercontinental (TANNURI, 1981).
} 


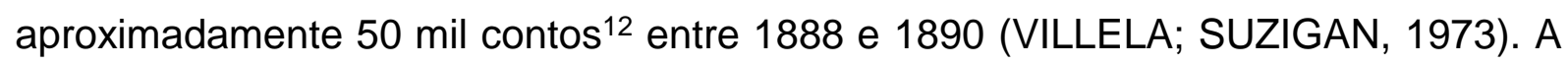
injeção de novos recursos contribuiu para o surgimento de um clima de otimismo que seria ainda intensificado com a mudança de regime político, formando as raízes da especulação que caracterizou ○ Encilhamento. Diversas instituições foram criadas com esse dinheiro, tendo muitas delas surgido apenas para tirar vantagem da situação. Tendo em vista a fragilidade do Império, Ouro Preto fez "vista grossa" aos abusos do sistema para não perder apoio político (BARBOSA, 2009).

As medidas, no entanto, não foram suficientes para evitar a queda do Império e, com a ascensão de Marechal Deodoro da Fonseca (1889-1891), Ruy Barbosa assumiu a pasta da Fazenda, empreendendo uma ambiciosa reforma monetária. Sua gestão configurou-se como a primeira tentativa de criar um programa econômico baseado em ideais papelistas desde a década de $1850^{13}$. Sua primeira medida foi a Lei de 17 de janeiro de $1890^{14}$.

A partir daquele momento, não só as notas dos bancos de emissão seriam aceitas como moeda legal, como também estes poderiam realizar qualquer tipo de transação financeira, como descontos, depósitos, operações cambiais, hipotecas, adiantamentos sobre meios de produção, empréstimos a curto e a longo prazo. As emissões foram divididas em três regiões, cada uma delas possuindo um banco com monopólio de emissão ${ }^{15}$. Se todas as emissões previstas fossem, de fato, realizadas, o meio circulante mais do que duplicaria. Ademais, o ministro promoveu a criação do Banco dos Estados Unidos do Brasil (BEUB), emissor da região central.

O objetivo de Ruy Barbosa era construir as bases para a execução do seu "plano de desenvolvimento" e transformar o sistema bancário no motor do crescimento econômico, de modo a promover a industrialização no Brasil. Nesse sentido, "sua atuação e pensamento constituem, juntamente com os de Mauá e Souza Franco, uma das grandes realizações do passado econômico brasileiro (...). Rui Barbosa foi um dos poucos ministros da Fazenda do período histórico brasileiro

\footnotetext{
12 Quantia que, em 1888, representava quase 25\% do meio circulante (BOTELHO JR., 2002).

$13 \mathrm{Na}$ década de 1850, a política econômica notadamente papelista implementada pelo ministro Souza Franco teria, segundo a literatura tradicional referente a esse período, provocado a crise de 1857. Para mais detalhes sobre essa crise, ver Schulz (1996) e Botelho Junior (2002).

${ }^{14}$ A Lei de 17 de janeiro de 1890 estabeleceu que "o Marechal Manoel Deodoro da Fonseca, Chefe do Governo Provisorio da Republica dos Estados Unidos do Brazil, constituido pelo Exército e Armada, em nome da Nação, decreta: Art. 1ํ As companhias ou sociedades anonymas, seja civil ou commercial o seu objecto, podem estabelecer-se sem autorização do Governo" (Fonte:www.camara.leg.br).

15 O Banco emissor do Norte possuía sede na Bahia; o Banco emissor do Sul, em Porto Alegre, enquanto o Banco Emissor do Centro sediava-se no Rio de Janeiro. Esses bancos estavam autorizados a emitir 150 mil, 100 mil e 200 mil contos de réis, respectivamente, sendo essas emissões lastreadas em títulos da dívida pública (FRANCO, 1983).
} 
que encarou devidamente a necessidade de desenvolver o país" (PELÁEZ; SUZIGAN, 1981, p. 143).

Além disso, Ruy Barbosa promoveu o surgimento de sociedades anônimas, ao elevar e facilitar de forma significativa o crédito. No entanto, segundo Peláez (1981) e Barbosa (2009), a falta de regulamentação e fiscalização necessárias das atividades dessas novas empresas provocou uma atividade intensa em um curto período de tempo. Dados de Botelho Jr. (2002) mostram que o número de empresas listadas na bolsa de valores do Rio de Janeiro aumentou de 90 para 450 em apenas um ano. Dentre estas, muitas não existiram na prática, sendo chamadas de "empresas fantasma". Assim, no início da primeira década republicana, a resolução do problema de falta de liquidez deu lugar a outro: a euforia no mercado acionário.

O Encilhamento foi um período caracterizado por ilusões de dinheiro fácil, fraudes na Bolsa de Valores do Rio de Janeiro e alucinação especulativa, seguidos por falências de bancos e diversos estabelecimentos, inflação e crise cambial. Conforme descreveram Villela e Suzigan (1973, p. 33) "uma febre de incorporações de novas empresas, que já vinha se manifestando desde o fim do Império, tomou impulso, não só devido à reforma bancária e das sociedades anônimas, como também ao clima de euforia criado com a inauguração do novo regime político". Também para Calógeras (1960, p. 179), “a República gerou uma euforia que talvez não pudesse ter sido controlada".

No entanto, já aqui fica claro que se tratava de um problema de regulação bancária - isto é, de pouco Estado na economia -, e não propriamente de política monetária. Apesar da grande visão econômica de Ruy Barbosa, faltou em sua execução a criação de um organismo fiscalizador das operações das novas instituições. Como praticamente não havia mecanismos de regulação, a emissão monetária ficou a cargo dos bancos privados, motivados por seus próprios interesses.

A Lei de 17 de janeiro de 1890 foi modificada tantas vezes ${ }^{16}$ que, no fim de 1890, havia nove bancos emitindo sobre lastros de naturezas distintas, de modo que a quantidade de dinheiro diferente em circulação confundia a população ${ }^{17}$. Ruy Barbosa renunciou em janeiro de 1891, devido a desavenças políticas, sendo

\footnotetext{
16 Para maior detalhamento sobre as modificações na Lei de 17 de janeiro de 1890, ver Barbosa (2009).

${ }_{17}$ Como sintetizado na crítica de Taunay (1971, p. 20), "Diariamente se viam na circulação monetária notas de todos os tipos, algumas novinhas, faceiras, artísticas, com figuras de bonitas mulheres e símbolos elegantes, outras sarapintadas às pressas, emplastradas de largos e nojentos borrões".
} 
substituído na pasta da Fazenda pelo Barão de Araripe, em um contexto de especulação desenfreada, desvalorização cambial e aceleração inflacionária.

Os sucessores de Ruy Barbosa na Fazenda, Barão de Araripe e Barão de Lucena, nada fizeram para conter a especulação e a emissão descontrolada de moeda e, segundo consta na literatura tradicional, não conseguiram evitar a inflação, a desvalorização cambial e o crash do Encilhamento. Segundo Prado (2003, p.15), "ambos eram pouco afeitos a complexidade da administração financeira e demonstraram incapacidade de lidar com a difícil situação econômica do país". Dessa forma, o movimento especulativo seguiria em curso em 1891. Para Franco (1989, p 23), "é certo que as hesitações e omissões que caracterizaram as gestões de Araripe e Lucena (...) favoreceram a crise cambial”. A literatura atribuiu a liquidação dos excessos do Encilhamento ao governo Campos Salles (1898-1902) e ao programa ortodoxo adotado pelo ministro Joaquim Murtinho.

\section{As consequências econômicas do papelismo, segundo a ortodoxia}

O Gráfico 01 exibe as taxas de inflação para o período de 1881 a 1899, as quais atingem um pico no ano de 1892. É possível perceber que a década de 1890 contrastou bastante com a anterior, ao menos no que se refere ao crescimento da inflação. Segundo Franco (1989), a oferta monetária aumentou 144\% entre 1890 e 1891 , sendo importante destacar que esse aumento do papel-moeda em circulação se deveu basicamente às emissões dos bancos, já que as do Tesouro se mantiveram estáveis, conforme revela o Gráfico 02. As emissões dos bancos mostraram uma significativa elevação a partir de 1890, ano da reforma monetária empreendida por Ruy Barbosa.

Gráfico 01. Taxa de inflação anual por custo de vida ${ }^{18}$ (ponderação FGV): 1881-1899

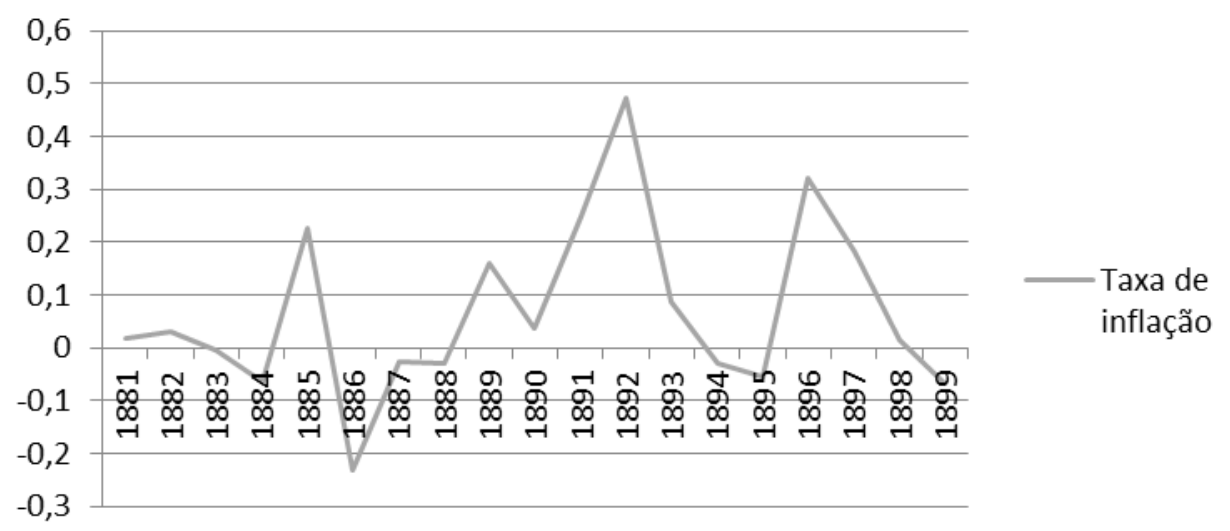

Fonte: Elaboração própria a partir de dados de Ipeadata.

18 Variação anual do índice de custo de vida, calculada a partir da série histórica da FGV iniciada em 1820. 
A literatura tradicional, embasada no ideário metalista, sustentou que a má condução da política monetária e a consequente instabilidade econômica que aqui se verificou provocaram um descrédito em relação ao novo regime político brasileiro, o que teria ocasionado uma grande fuga de capitais que fez a taxa de câmbio se depreciar do almejado patamar de 27 pence por mil réis para 12 pence por mil réis em $1891^{19}$, evidenciando um cenário de crise.

Gráfico 02. Emissões dos bancos privados e do Tesouro Nacional: 1888-1892 (em mil contos de réis).

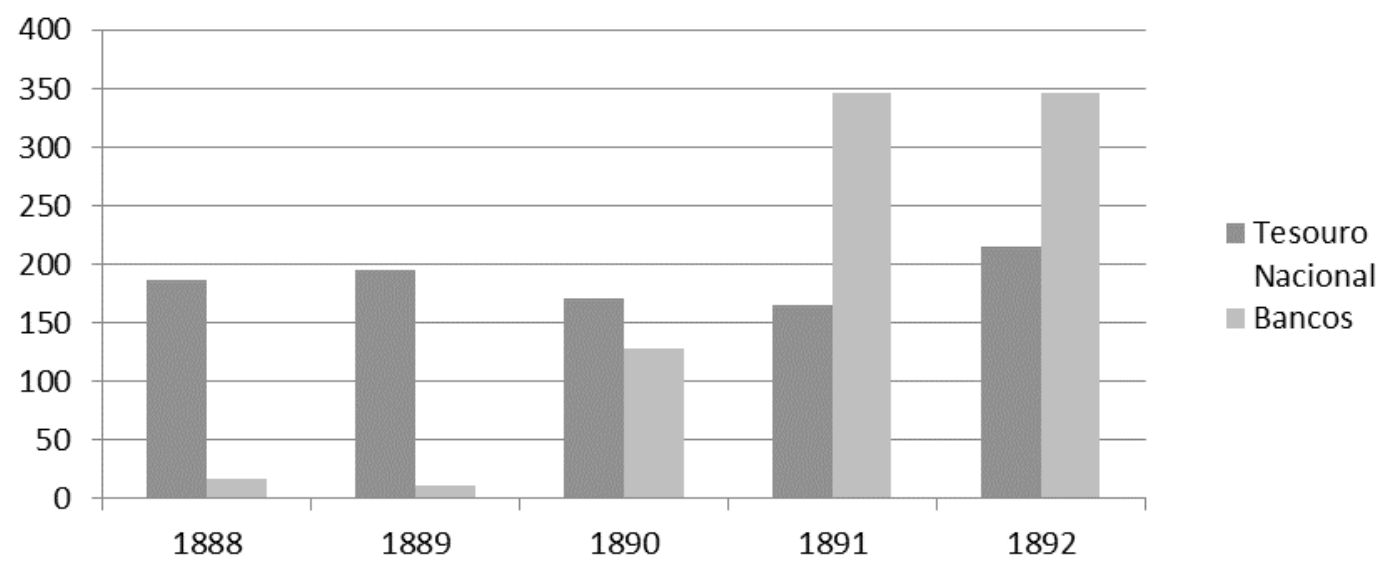

Fonte: Elaboração própria a partir de dados de IBGE (1990, p.545).

Depois de 1891, as dificuldades cambiais tornaram-se crônicas, conforme é possível observar no Gráfico 03. A taxa de câmbio flutuou entre 9 e 10 pence por mil réis até o final de 1895. A crise do Encilhamento estaria, portanto, segundo a abordagem ortodoxa ${ }^{20}$, enraizada em políticas econômicas papelistas, isto é, seria consequência do excesso de emissão monetária realizado pelo governo.

A primeira notável consequência do derretimento da taxa de câmbio foi o estímulo à ampliação da fronteira cafeeira - uma vez que as receitas dos cafeicultores se elevavam em moeda nacional -, o que levou às super safras de 1895 e $1896^{21}$ e a uma consequente queda nos preços do café no mercado internacional. Justamente nesse período começaram a surgir as primeiras reinvindicações defendendo uma intervenção mais explícita do governo no setor

\footnotetext{
19 Durante todo o Império, o nível mais baixo da taxa de câmbio foi de 17 pence, em meados da década de 1860.

${ }^{20}$ Dentre os autores que defendem essa posição, estão Calógeras (1960) e Schulz (1996).

21 As super safras de 1895 e 1896 se devem, em grande medida, aos investimentos feitos na plantação de café durante o período de euforia do Encilhamento. O tempo de maturação (ou seja, o tempo entre o plantio e a colheita) do café é de cerca de 5 anos.
} 
cafeeiro, que apenas uma década mais tarde culminaram nos programas prékeynesianos de compra e queima de café.

Gráfico 03. Comportamento da taxa de câmbio: 1888-1900 (em pence por mil réis).

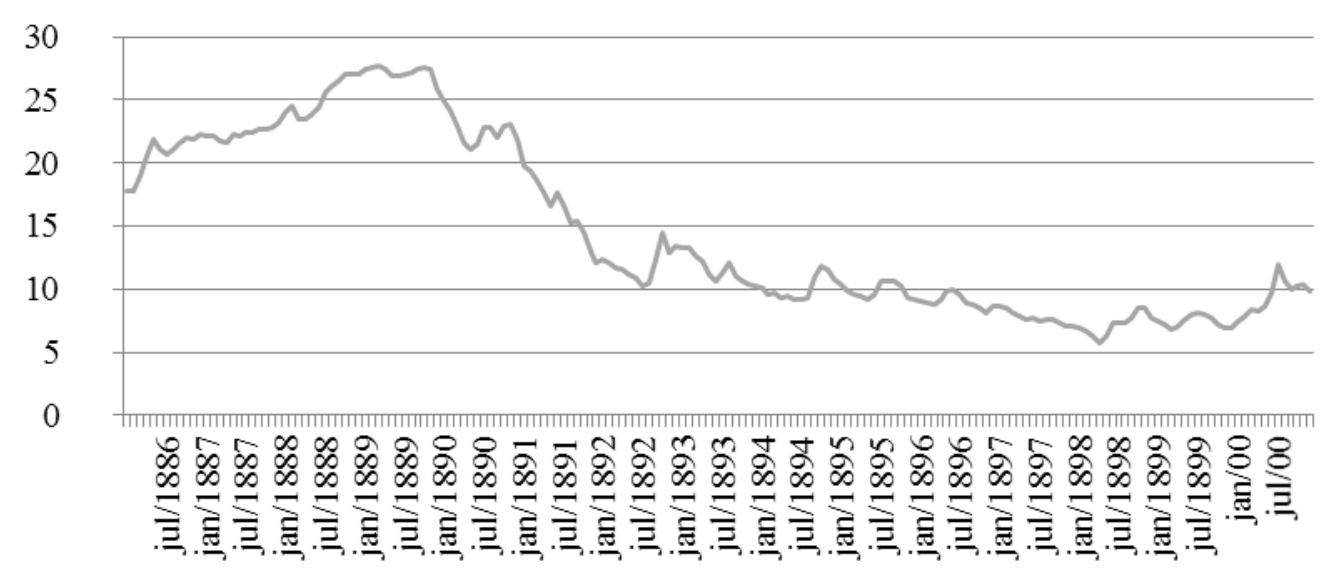

Fonte: Elaboração própria a partir de dados de Ipeadata.

A desvalorização cambial também deteriorou as contas do governo. As despesas do governo se viram comprometidas, uma vez que a desvalorização do mil réis elevava, em moeda nacional, a dívida externa e as despesas com os serviços dessa dívida. As receitas do governo deterioraram-se igualmente, já que a depreciação cambial desestimulou as importações, reduzindo as receitas que provinham dos impostos alfandegários. A consequência foi uma elevação do déficit fiscal, que passou de cem mil contos no ano de seu pior desempenho, como mostra o Gráfico 04.

Gráfico 04. Saldo orçamentário do governo nacional: 1889-1894 (em contos de réis)

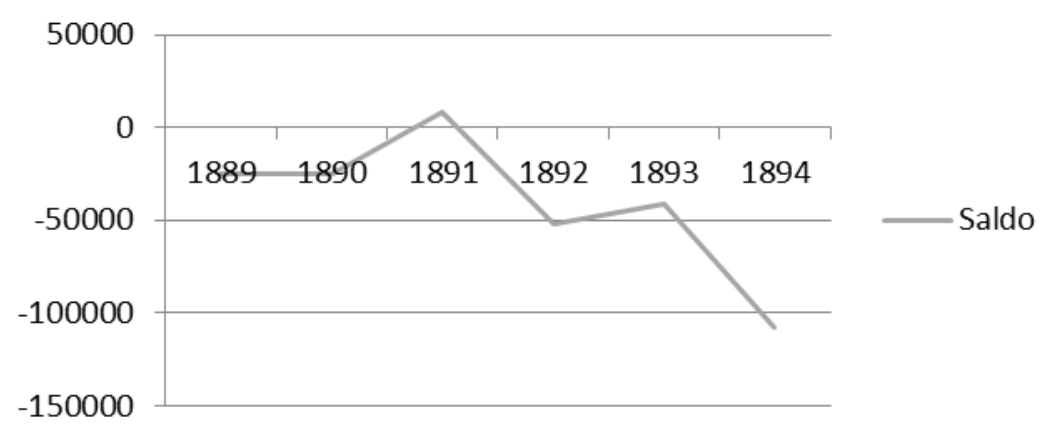

Fonte: Elaboração própria a partir de dados de IBGE (1990, p.120).

Uma das interpretações, associada à tradição ortodoxa, sugere que a inflação e a desvalorização cambial teriam sido decorrentes de uma má gestão da política monetária. No entanto, deve-se perceber que, no mesmo período em que o Brasil sofreu com a crise interna, a Argentina declarava moratória, fato que levou à falência do banco inglês Baring Brothers e a uma consequente agitação dos mercados 
financeiros internacionais, com importantes consequências sobre a economia brasileira.

\section{A moratória argentina e a crise do banco Baring Brothers}

Na segunda metade do século XIX, a Argentina possuía características de uma economia predominantemente primário-exportadora, com destaque para as exportações de lã, carne, couro e cereais, principalmente o trigo. Entretanto, no início dos anos 1880, a produção de cereais estava limitada pela falta de estradas de ferro e pela escassez de população. Por isso, nas décadas que se seguiram, o governo tomou diversas medidas de estímulo à imigração no país, como a Lei Avellaneda 22 de 1876, cujo objetivo era promover o aumento populacional.

Uma vez que o problema de escassez de população estava sendo resolvido, a construção de ferrovias foi financiada, ao longo dos anos 1880 , quase totalmente com capitais externos, cuja entrada possibilitou também o aumento dos gastos do governo. É importante destacar que o fim dos anos 1880 caracterizou-se por uma febre de empréstimos públicos concedidos a países periféricos. A conjunção desses fatores levou a Argentina a experimentar um período de intenso crescimento econômico, marcado principalmente por sua grande integração aos mercados internacionais, especialmente à Inglaterra ${ }^{23}$. Assim, a grande entrada de capitais na Argentina no final do século XIX teve como contrapartida o crescimento da dívida externa, que aumentou consideravelmente entre 1880 e 1890 (FILOMENO, 2010).

Porém, se o afluxo de capitais externos mostrou-se favorável ao crescimento e desenvolvimento econômico argentino em um primeiro momento, aos poucos o serviço da dívida foi se transformando em uma pesada carga. A breve recessão mundial do final dos anos 1880 reduziu a exportação de capitais pelas regiões centrais. A brusca contração do influxo de capital proveniente do exterior fez com que o serviço da dívida externa dos Estados periféricos contraída ao longo da década recaísse sobre as exportações, as quais atravessavam uma fase ruim. $\mathrm{Na}$ Argentina, o preço do trigo sofreu um declínio de $45 \%$ justamente nesse período (FILOMENO, 2010)

Como o balanço de pagamentos argentino começou a apresentar problemas a partir desse momento, os fluxos de capitais para esse país se reduziram ainda

${ }^{22}$ A Lei Avellaneda teve como inspiração a Homestead Act americana e pretendia promover a imigração e a colonização de extensos territórios até então inexplorados (RAPOPORT, 2003).

${ }^{23}$ Segundo Rapoport (2003), os investidores estrangeiros escolheram a Argentina para depositar seus capitais principalmente porque obtinham picos de rentabilidade de até $15 \%$ de dividendos anuais, que não eram alcançados facilmente em outras partes do mundo. 
mais. A elevação das taxas de juros britânicas, por sua vez, tornou a situação insustentável. Na virada da década de 1880 para a de 1890, as exportações não mais se expandiam em magnitude suficiente para fazer frente aos serviços da dívida. Assim, era inevitável que a crise estourasse tão logo cessasse o fluxo de capitais externos para a Argentina. Isso ocorreu quando a desconfiança em relação à capacidade de pagamento do governo argentino se disseminou no exterior e a casa Baring Brothers só pôde continuar vendendo os títulos do país no mercado londrino com enormes perdas.

Assim, no início da década de 1890, emergiu uma crise externa bancária e financeira. O primeiro dos eventos foi a quebra do Banco Constructor de la Plata, que gerou uma forte oposição política a esquemas de corrupção e clientelismo. Naquele ano, a instabilidade política que se instaurou e a quebra da safra de trigo apenas anunciaram uma crise mais grave, a qual teve início em novembro, quando os mercados financeiros de Londres não permitiram o adiamento do pagamento da dívida externa argentina e o país teve de declarar publicamente a incapacidade de pagar suas dívidas (LENZ, 2006).

Diante da situação de insolvência, o banco Baring Brothers fechou provisoriamente suas portas e quase faliu, tendo sido rapidamente socorrido pelo Banco da Inglaterra. A expectativa de intervenção do governo inglês na Argentina, no entanto, não se concretizou ${ }^{24}$. Alguns dos principais bancos argentinos se declararam em bancarrota e acabaram entrando em liquidação. Assim, "outorgou-se uma moratória geral, enquanto a cotação dos títulos e ações dos bancos e empresas mais importantes declinava de forma espetacular. A crise levou à quase paralisação da atividade econômica 25". (FILOMENO, 2010, p.9).

A intensa e duradoura relação entre o governo argentino e o banco inglês Baring Brothers teve início em 1824, com um empréstimo concedido à província de Buenos Aires para a construção de seu porto. O empréstimo só começou a ser pago a partir de 1857, quando a província negociou um refinanciamento em longo prazo, o qual cumpriu estritamente (LENZ, 2001). O banco Baring estava, portanto, ligado à Argentina como principal agente fornecedor de empréstimos, por meio do qual foi possível ao governo argentino a obtenção de uma grande quantidade de fundos no

\footnotetext{
${ }^{24}$ Segundo Lenz (2010), o episódio é considerado o mais claro e enfático exemplo de política de não intervenção.

${ }^{25}$ Crises econômicas envolveram Inglaterra, Argentina, México, Uruguai e Austrália de 1890 a 1893. O "default" argentino, por sua vez, foi seguido por Austrália, Portugal e Grécia, em 1893, e Brasil, em 1898 (FILOMENO, 2010).
} 
mercado britânico. No último quarto do século XIX, o banco estava bastante envolvido no boom de investimentos ingleses na Argentina e começou a ter problemas no fim de 1888, quando patrocinou em Londres o fracassado lançamento das ações da Sociedad de las Aguas Corrientes y Drenaje de Buenos Aires.

O banco Baring participou da criação e assumiu a promoção da Sociedad de las Aguas Corrientes y Drenaje de Buenos Aires em troca de obter do governo argentino a concessão das obras de drenagem e provisão de águas. A expectativa era de que a venda dessas ações gerasse um lucro fantástico para a casa Baring, embora se constituísse em um negócio de altíssimo risco. Porém, em 1889, os trabalhos da Companhia estavam atrasados e as obras exigiam somas muito maiores do que as colocadas no orçamento inicial (LENZ, 2001). No entanto, para Triner \& Wandschneider (2005), a falência da Sociedad de las Aguas Corrientes y Drenaje de Buenos Aires foi só o mais dramático dos problemas financeiros, os quais atingiram uma profundidade ainda maior no final dos anos 1891. O termo Crise Baring é utilizado normalmente para se referir à situação crítica da casa bancária londrina Baring Brothers em função da moratória argentina e do insucesso de seus investimentos de risco no país em 1890. A notícia de que o Baring Brothers havia chegado perto da falência devido à instabilidade argentina, por sua vez, causou um enorme pânico nos mercados financeiros mundiais, que ficou conhecido como Pânico de 1890.

Triner \& Wandschneider (2005) chamam a atenção para o fato de o Brasil e a Argentina desempenharem funções bastante semelhantes no fim do século XIX como exportadores de commodities. Enquanto o Brasil era o maior produtor mundial de café - e, por alguns anos, borracha -, a Argentina produzia e exportava porcentagens significativas de carne, lã e cereais ${ }^{26}$. A partir de 1890 , as inversões inglesas na Argentina se reduziram em função da moratória no país. Diante desse cenário, vários outros agentes financeiros que possuíam investimentos de risco em países da América Latina resolveram colocar seus capitais em locais mais seguros, o que provocou uma enorme fuga de capitais no Brasil e nos outros países da América Latina. Franco (1983, p.140) sustenta esse fato, ao destacar que "a liquidação da crise financeira, originada pela falência dos Baring (...) teve efeito devastador sobre as cotações dos títulos sul-americanos e originou uma duradoura desconfiança para com esses títulos".

\footnotetext{
${ }^{26}$ No entanto, segundo Triner \& Wandschneider (2005), os produtos argentinos não tinham a mesma predominância que o café brasileiro nos mercados mundiais, devido à competição com os produtores canadenses e australianos.
} 


\section{Os canais de contágio da crise para o Brasil}

O Brasil, em sua condição de país periférico do sistema, certamente não estava imune a abalos de proporções internacionais. O Pânico de 1890 produziu consequências notáveis sobre a confiança dos agentes internacionais, que, temendo novas moratórias no continente, resolveram retirar seus capitais investidos no país. No entanto, esse foi apenas o mais óbvio dos canais de contágio. Nesta seção, serão analisadas, por meio de dados do balanço de pagamentos e do valor das exportações brasileiras, três formas de transmissão da crise externa para o cenário interno.

O primeiro canal de contágio que se pode pensar é a queda dos preços dos produtos primários no mercado internacional - no Brasil, o café, que representava quase $70 \%$ da pauta de exportações -, uma vez que, em momentos de crise internacional, a previsão é de que haja uma contração do consumo nos países centrais. Como os produtos primários apresentam geralmente uma baixa elasticidade-renda, eles sofrem inexoravelmente com a redução da demanda em períodos de crise sistêmica, conforme argumentou Furtado (1959).

As importações, por outro lado, não se reduzem de imediato, tendo em vista que o efeito da queda do valor das exportações sobre a procura por importações é lento (FURTADO, 1959). Dessa forma, é comum que se observe inicialmente um déficit na balança comercial. Além disso, a redução do preço das mercadorias importadas ocorre de forma mais demorada do que a dos produtos primários exportados, gerando uma piora nos termos de intercâmbio. A Tabela 01 e a Tabela 02 mostram os preços do café em franco francês e seu valor de exportação em libra esterlina, bem como as quantidades exportadas do produto brasileiro.

Quando analisados em franco francês, como na Tabela 01, os preços do café parecem apresentar uma breve, porém não desprezível redução após a crise do Baring. Depois de atingir, em 1887, 85,55 francos franceses por saca de cinquenta quilos, esse valor caiu aproximadamente $23,3 \%$ no ano seguinte. A interpretação que se pode auferir dessa redução inicial é que esta foi consequência da breve depressão que atingiu a Europa no fim da década de 1880. Essa queda no preço do café, quando se utilizam os dados em franco, mostra-se muito mais acentuada do que aquela decorrente da crise Baring, quando o preço do produto caiu $6 \%$. Desse modo, o efeito da redução do valor das exportações, tal como fora previsto por Furtado, não parece ter sido tão forte na eclosão da crise Baring como fora no fim da 
década de 1880 , muito embora uma queda de $6 \%$ seja significativa. A redução do preço do café continuou no ano seguinte, tendo o produto recuperado seu valor apenas em 1893, a partir de quando a economia internacional começou a se recuperar, após a deflagração da crise gerada pela falência do Baring.

Tabela 01. Preços do café: 1885-1893 (em franco francês)

\begin{tabular}{ccc}
\hline Ano & Preço do café (sacas de 50) & Variação (\%) \\
1885 & 40,25 & \\
1886 & 45,04 & 11,9 \\
1887 & 85,55 & 89,9 \\
1888 & 65,62 & $-23,3$ \\
1889 & 70,77 & 7,8 \\
1890 & 72,80 & 2,9 \\
1891 & 68,43 & $-6,0$ \\
1892 & 64,85 & $-5,2$ \\
1893 & 85,79 & 32,3 \\
\hline
\end{tabular}

Fonte: Ipeadata

A Tabela 02, por sua vez, analisa a quantidade e o valor, em libras, da exportação do café no período de 1887 a 1898. O valor do produto brasileiro, após dois anos de forte crescimento, apresenta redução em dois anos seguidos: $6 \%$ de 1889 para 1890 e 1,6\% de 1890 para 1891. Essa queda pode ser atribuída diretamente à repercussão mundial da crise do Baring e seu efeito sobre a redução das importações nos países centrais, tal como previu Furtado. Em 1892, o café recupera seu valor e a quantidade exportada também se amplia. Entretanto, a partir de 1896, tem início um período de quedas acentuadas no preço internacional do café, decorrente do incentivo que a desvalorização cambial teve sobre a ampliação da fronteira cafeeira.

Tabela 02. Quantidade e valor da exportação do café em grão: 1887-1898

\begin{tabular}{cccc}
\hline Anos & $\begin{array}{c}\text { Quantidade (mil } \\
\text { sacas de 60kg) }\end{array}$ & $\begin{array}{c}\text { Valor em milhares } \\
\text { de libras ouro }\end{array}$ & Variação (\%) \\
1887 & 1.694 & 6.958 & \\
1888 & 3.444 & 10.857 & 56,0 \\
1889 & 5.586 & 18.983 & 74,8 \\
1890 & 5.109 & 17.850 & $-6,0$ \\
1891 & 5.373 & 17.561 & $-1,6$ \\
1892 & 7.109 & 22.028 & 25,4 \\
1893 & 5.307 & 21.712 & $-1,4$ \\
1894 & 5.582 & 20.884 & $-3,8$ \\
1895 & 6.720 & 22.385 & 7,2 \\
1896 & 6.744 & 19.663 & $-12,2$ \\
1897 & 9.463 & 16.506 & $-16,1$ \\
1898 & 9.267 & 13.830 & $-16,2$ \\
\hline
\end{tabular}

Fonte: IBGE (1990, p.312).

A Tabela 03 mostra uma estimativa para o balanço de pagamentos brasileiro no período de 1880 a 1897, enquanto a Tabela 04 atenta para a piora nos termos de 
intercâmbio a partir do momento em que a crise externa atingiu o Brasil, embora o que chame mais a atenção sejam os anos finais da década. Atentando-se para as receitas de exportações, tem-se que estas não se reduziram após a crise do Baring, tendo até mesmo crescido até meados dos anos 1890. A explicação disso está justamente na Tabela 02: apesar da queda no valor do café, a manutenção do volume exportado impediu que as receitas de exportações se reduzissem.

Tabela 03. Estimativa para o Balanço de Pagamentos do Brasil: 1880-1897 (em milhares de libras)

\begin{tabular}{cccccccc}
\hline Anos & Exportações & Importações & $\begin{array}{c}\text { Balança } \\
\text { Comercial }\end{array}$ & $\begin{array}{c}\text { Saldo de } \\
\text { Serviços }\end{array}$ & $\begin{array}{c}\text { Transações } \\
\text { Correntes }\end{array}$ & $\begin{array}{c}\text { Conta } \\
\text { Capital }\end{array}$ & $\begin{array}{c}\text { Saldo } \\
\text { Global }\end{array}$ \\
1880 & 21.249 & 16.529 & +4.720 & -4.048 & +672 & +1.492 & +2.164 \\
1881 & 19.138 & 16.621 & +2.517 & -4.244 & -1.727 & +920 & -807 \\
1882 & 17.378 & 16.782 & +596 & -4.283 & -3.687 & +1.146 & -2.541 \\
1883 & 19.493 & 18.187 & +1.306 & -4.609 & -3.303 & +10.195 & +6.892 \\
1884 & 19.504 & 15.381 & +4.123 & -4.665 & -542 & -99 & -641 \\
1885 & 15.110 & 15.306 & -196 & -4.079 & -4.275 & +244 & -4.031 \\
1886 & 20.502 & 16.120 & +4.382 & -5.028 & -646 & +6.857 & +6.211 \\
1887 & 11.703 & 9.690 & +2.013 & -4.521 & -2.508 & +4.673 & +2.165 \\
1888 & 21.714 & 19.724 & +1.990 & -5.247 & -3.257 & +21.141 & +17.884 \\
1889 & 28.552 & 24.002 & +4.550 & -5.276 & -726 & +11.189 & +10.463 \\
1890 & 26.382 & 24.019 & +2.363 & -6.816 & -3.753 & +273 & -3.480 \\
1891 & 27.136 & 25.565 & +1.571 & -7.610 & -6.039 & +39 & -6.000 \\
1892 & 30.854 & 26.302 & +4.552 & -6.755 & -2.203 & -1.466 & -3.669 \\
1893 & 32.007 & 26.215 & +5.792 & -7.601 & -1.809 & +3.536 & +1.727 \\
1894 & 30.491 & 27.145 & +3.346 & -7.335 & -3.989 & +363 & -3.626 \\
1895 & 32.586 & 29.212 & +3.374 & -7.121 & -3.747 & +6.044 & +2.297 \\
1896 & 28.333 & 27.880 & +453 & -7.731 & -7.278 & +7.275 & -3 \\
1897 & 25.883 & 22.990 & +2.893 & -8.170 & -5.277 & +5.254 & -23 \\
\hline
\end{tabular}

Fonte: Franco (1983, p.50).

Tabela 04. Evolução dos termos de intercâmbio no Brasil: 1888-1899 (base $1893=100$ )

\begin{tabular}{cccccccccccccc} 
Anos & 1888 & 1889 & 1890 & 1891 & 1892 & 1893 & 1894 & 1895 & 1896 & 1897 & 1898 & 1899 \\
$\begin{array}{c}\text { Relação de } \\
\text { troca }\end{array}$ & 92 & 87 & 87 & 83 & 84 & 100 & 91 & 88 & 77 & 60 & 58 & 56 \\
\hline
\end{tabular}

Fonte: Ipeadata.

Portanto, ao menos em relação ao efeito pelo lado das receitas de exportações, o Brasil parece ter sido muito mais afetado pela breve recessão do fim dos anos 1880 - quando estas caíram de $£ 20.502$ mil para $£ 11.703$ mil - do que pela crise do Baring. Pela Tabela 05, pode-se perceber que as remessas de lucros também aumentaram a partir da crise do Baring. Apesar de o Brasil ter sido contaminado pelo lado das exportações, esse efeito certamente seria muito maior não fosse o fato de que a crise afetou muito mais a Inglaterra, que não era a principal consumidora do café brasileiro, tendo em vista a preferência inglesa pelo chá. 
O principal destino de nossas exportações de café, os Estados Unidos, sofreram os efeitos da crise do Baring com certo atraso, a partir do ano de 1893, quando se reduzem tanto os preços como as quantidades de café exportado. Dessa forma, ainda que os britânicos tenham reduzido seu consumo de café, essa redução, a nível mundial, não teria sido forte o suficiente, o que manteve as receitas provenientes das exportações. Conforme afirma Bastos (2008, p.13), "se o mercado britânico fosse o principal mercado de destinação das exportações, a simultaneidade da contração das exportações de bens e das importações de capital - postulada por Furtado para explicar a vulnerabilidade externa da economia brasileira - teria se verificado na crise da década de 1890".

Tabela 05. Remessas de lucros e Saldo da Conta de Serviços: 1887-1893 (em milhares de libras)

\begin{tabular}{ccc}
\hline Ano & Remessas de lucros & $\begin{array}{c}\text { Total Conta de } \\
\text { Serviços }\end{array}$ \\
1887 & 225 & -4.521 \\
1888 & 230 & -5.247 \\
1889 & 244 & -5.276 \\
1890 & 639 & -6.816 \\
1891 & 312 & -7.610 \\
1892 & 362 & -6.755 \\
1893 & 316 & -7.601 \\
\hline
\end{tabular}

Fonte: Franco (1989, p.47)

O segundo meio possível de contágio seria a redução do recolhimento de impostos pelo governo, uma vez que a principal fonte de arrecadação do governo federal nesse período consistia justamente nos tributos sobre importações, as quais decresceriam em momentos de crise. Porém, nos anos seguintes à crise Baring, as importações não sofreram nenhuma redução. Desse modo, tem-se que, apesar das repercussões mundiais da crise, que provocaram o Pânico de 1890, tanto as exportações como as importações seguiram crescendo até o fim do século XIX. A balança comercial, por conseguinte, manteve-se superavitária durante toda a década de 1890.

O que se conclui disso é que, se houve "contágio" da crise para o Brasil, este não se deu pelo lado da balança comercial. A transmissão da crise parece ter ocorrido principalmente pela terceira e última forma de contágio que se pode pensar: a inevitável redução dos fluxos de capitais para o Brasil e para os outros países da periferia. Embora não fossem os principais consumidores do café brasileiro, os ingleses eram nossos principais credores internacionais. Como a crise do Baring 
afetou fortemente o mercado londrino, os capitais britânicos foram retirados, por medida de precaução, dos países que representassem algum risco de moratória.

Desde o início da década de 1880, como é possível observar na Tabela 03, a Conta Corrente do balanço de pagamentos brasileiro já apresentava crescentes e persistentes déficits. Os credores internacionais, após a moratória argentina, começaram a desconfiar de que o Brasil também poderia declarar a incapacidade de pagar seus débitos externos, uma vez que esse saldo negativo vinha sendo constantemente financiado pelo saldo positivo na Conta Capital, a exemplo do que ocorrera na Argentina e, possivelmente, em outros países pertencentes à periferia do sistema.

No ano da crise do Baring, o balanço de pagamentos brasileiro fechou com saldo negativo após nove anos de superávits. Esse sinal negativo, no contexto da moratória argentina, provocou uma percepção pessimista dos credores internacionais em relação ao pagamento da dívida externa brasileira. Assim, nos dois anos que se seguiram, a fuga de capitais intensificou-se não apenas em função da repercussão da crise do Baring, mas também devido ao efeito que o crescimento do déficit em Transações Correntes brasileiro teve sobre os mercados financeiros internacionais. Desse modo, o que se observa é justamente a correlação perversa, em momentos de crise, entre a Conta Corrente e a Conta Capital do balanço de pagamentos, cujos sinais negativos reforçam-se mutuamente - a exemplo do que defendeu Furtado, embora ele auferisse que a crise começava pela balança comercial.

O Brasil sofreu fuga de capitais nos três anos que se seguiram a partir da crise do Baring, tendo passado de um superávit de £21.141 mil para um déficit de $£ 1.466$ mil. Portanto, a transmissão da crise parece ter se dado muito mais pelo lado financeiro do que pela balança comercial, reduzindo consideravelmente os fluxos de capitais para o Brasil. ${ }^{27}$ No ano seguinte à crise, o Brasil registrou seu pior desempenho no balanço de pagamentos desde 1880, um déficit de $£ 6.000$ mil que não seria alcançado novamente até o fim do século. Tal fato confirma a hipótese de que países periféricos, como o Brasil, sofrem permanentemente com problemas de

\footnotetext{
27 Bastos (2008) procurou demonstrar que Furtado (1959) subestimara o papel que a redução dos fluxos financeiros tinha na crise sobre as economias periféricas, dando muito mais ênfase ao fluxo comercial de bens. Nesse caso da crise do Baring, por exemplo, o Brasil foi muito mais afetado pela dependência dos fluxos financeiros do que pela queda do valor de seus produtos exportados. A relação financeira era mais aproximada com a Inglaterra, enquanto que a relação comercial (no caso do café) era muito mais intensa com os EUA - que foram muito menos afetados pela crise do Baring, e com algum atraso.
} 
balanço de pagamentos, em função de serem exportadores de produtos primários e importadores de capital estrangeiro.

A Tabela 06, por sua vez, exibe a reação do câmbio no ano que se seguiu à notícia da crise do banco Baring, sendo notável o fato de a taxa de câmbio ter se reduzido em todos os meses, exceto dois. Em um ano, a taxa de câmbio brasileira se desvalorizou $48 \%$, saindo de 23 pence para 12 pence por mil réis, e chegou a seis pence por mil réis no fim da década de 1890, só tendo iniciado uma recuperação significativa na virada do século, quando os fluxos de capitais foram revitalizados em direção ao Brasil.

Tabela 06. Taxa de câmbio mensal: 1890-1891 (em pence por mil réis)

\begin{tabular}{cccc}
\hline Mês & $\begin{array}{c}\text { Taxa de } \\
\text { câmbio }\end{array}$ & Variação (\%) & Variação Acumulada (\%) \\
Novembro/1890 & $231 / 8$ & & \\
Dezembro/1890 & $217 / 8$ & $-5,4$ & $-5,4$ \\
Janeiro/1891 & $197 / 9$ & $-10,0$ & $-14,5$ \\
Fevereiro/1891 & $191 / 3$ & $-2,2$ & $-16,4$ \\
Março/1891 & $185 / 8$ & $-4,0$ & $-19,5$ \\
Abril/1891 & $172 / 3$ & $-5,1$ & $-23,6$ \\
Maio/1891 & $165 / 9$ & $-6,3$ & $-28,4$ \\
Junho/1891 & $173 / 5$ & 6,3 & $-23,9$ \\
Julho/1891 & $165 / 9$ & $-6,0$ & $-28,4$ \\
Agosto/1891 & $151 / 3$ & $-7,4$ & $-33,7$ \\
Setembro/1891 & $151 / 3$ & 0,0 & $-33,7$ \\
Outubro/1891 & $142 / 5$ & $-6,1$ & $-37,7$ \\
Novembro/1891 & 13 & $-10,0$ & $-43,8$ \\
Dezembro/1891 & 12 & $-7,7$ & $-48,1$ \\
\hline
\end{tabular}

Fonte: Ipeadata

O Gráfico 05 exibe a relação entre a taxa de inflação e a taxa de variação cambial - medida em mil réis por pence para facilitar a visualização - entre os anos de 1887 a 1893. Este gráfico revela que a desvalorização cambial antecede a aceleração inflacionária após a crise do Encilhamento. Deste modo, esta causalidade parece inequívoca: a consequente fuga de capitais que se seguiu à crise do Baring provocou uma espiral inflacionária. O gráfico revela que a aceleração inflacionária se inicia depois do momento em que o câmbio começou a se desvalorizar com uma defasagem aproximada de um ano: somente a partir de 1891, um ano após a quebra do Baring, os preços internos começaram a disparar um ano depois de iniciada a desvalorização cambial, que atinge seu ápice em 1891 - a inflação, por sua vez, atinge seu ápice no ano seguinte. A seguir, a desaceleração da taxa de desvalorização cambial desencadeia uma desaceleração da taxa de inflação. A correlação entre a trajetória da taxa de câmbio e da inflação nesses anos em tela pode ser visualmente comprovada. 
Gráfico 5. Taxa de inflação e taxa de variação cambial (em mil réis por pence): 1887 - 1893

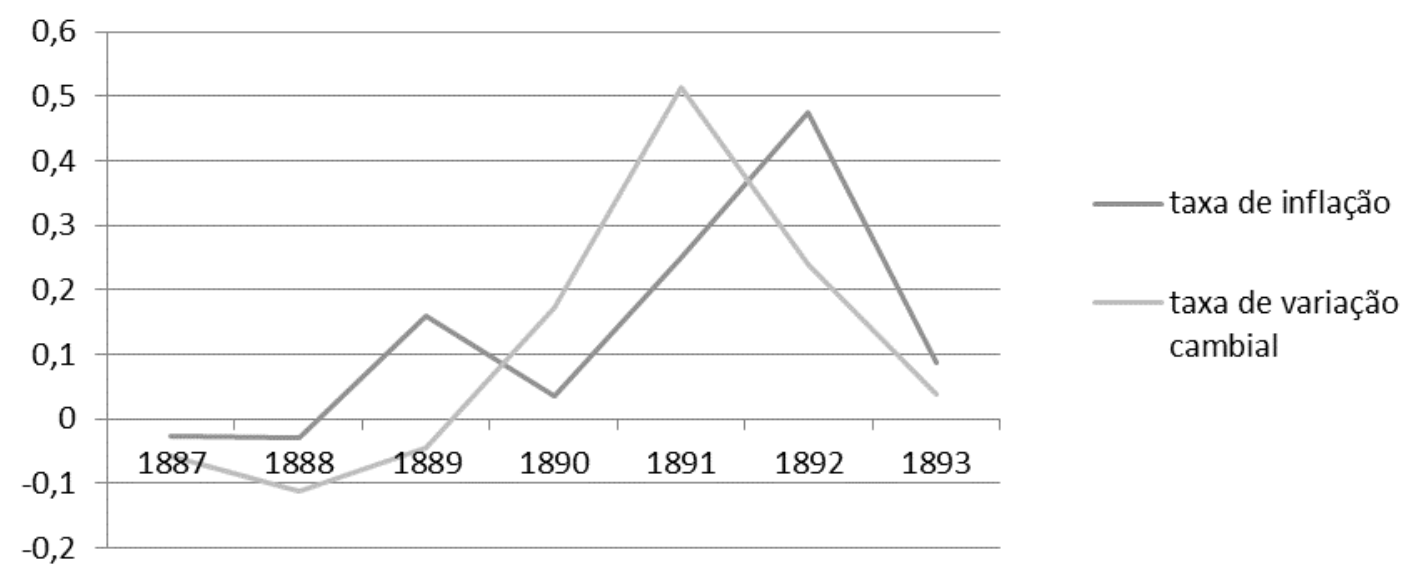

nte: Elaboração própria a partir de dados de Ipeadata.

Por outro lado, outras evidências fragilizam a validade da hipótese quantitativista, segundo a qual a expansão monetária de Ruy Barbosa teria provocado aceleração inflacionária. A despeito da crise econômica do Encilhamento, o viés expansivo da política monetária somente será revertido na virada do século, sob a gestão do Ministro da Fazenda Joaquim Murtinho. Já a inflação cai a partir de 1893, volta a se acelerar em 1896, e cai novamente em seguida (Gráfico 01). Não há, a rigor, uma correlação entre uma política monetária que permanece sob o viés expansivo durante toda a década e uma taxa de inflação que descreve trajetória intermitente. Sob o risco da repetição - que, contudo, é necessária - é importante ressaltar a correlação entre a inflação e a taxa de câmbio entre 1890 e 1893.

Não há, de acordo com o Gráfico 01, um processo inflacionário crônico em curso, mas episódios pontuais de aceleração e desaceleração inflacionária, que contrasta com a contínua expansão monetária durante a década de 1890. Por outro lado, a inflação começa a desacelerar já a partir de 1897 - antes, portanto, da política monetária contracionista de Joaquim Murtinho.

Além disso, outras evidências enfraquecem a hipótese de aceleração inflacionária decorrente da expansão monetária de Ruy Barbosa. O mecanismo que deveria transmitir a expansão monetária para os preços teria de supor: (a) crescimento generalizado da demanda por meio de acesso a amplos segmentos da população à moeda ofertada, e (b) alguma rigidez da capacidade produtiva, incapaz de suprir a demanda crescente, inclusive por meio de importações. Esta última hipótese deve ser descartada, porque mesmo a literatura crítica da reforma de Ruy Barbosa reconhece o crescimento da produção e da capacidade produtiva durante 0 período. Suzigan (1986, p. 83) mostra uma queda do investimento na indústria 
somente na segunda metade da década de 1890, mas uma trajetória bastante satisfatória desta variável na primeira metade. Por outro lado, mesmo que houvesse alguma rigidez na oferta, o excesso de demanda poderia ser satisfeito por importações, as quais cresceram em toda a primeira metade da década, exceto em 1893 (Tabela 03). Finalmente, a hipótese de um excesso de demanda causado pelo excesso de moeda teria de supor a existência de uma demanda por bens e serviços que se encontrasse reprimida antes da reforma de Ruy Barbosa.

De fato, a literatura aponta a eminência de uma crise de liquidez por ocasião da Abolição e das imigrações de estrangeiros para trabalhar no Brasil (ver, por exemplo, Franco, 1989), mas não há relato de penúria por parte das camadas de rendas médias e altas, que são exatamente os segmentos beneficiados pela expansão monetária. ${ }^{28}$ Por outro lado, o assalariamento dos ex-escravos não lhes elevou subitamente o padrão de vida a ponto de provocar um excesso de demanda capaz de acelerar a inflação, haja vista a ampla literatura que reconhece a tragédia social que significou uma abolição desacompanhada de políticas de integração social dos ex-escravos. Restaria então, numa abordagem mais favorável ao quantitativismo/monetarismo, a hipótese de um desequilíbrio entre oferta e demanda causado pelos imigrantes estrangeiros. De fato, a absorção repentina de milhares de trabalhadores estrangeiros iria requerer a capacidade de produção de víveres e outros bens e serviços. Se as importações fossem insuficientes em razão dos limites impostos pela restrição externa, na hipótese do ajuste ocorrer por meio de inflação, esta teria sido obviamente causada não pelo excesso de moeda provocado pela reforma de Ruy Barbosa, mas sim por um desequilíbrio estrutural entre oferta e demanda decorrente das imigrações, e não da expansão monetária.

Descartada a possibilidade de uma inflação causada por excesso de moeda, há que se verificar se outros itens da formação de preços poderiam ter contribuído para a aceleração inflacionária deste período. Em geral, as abordagens de inflação de custos investigam a trajetória das principais variáveis que integram o processo de formação de preços: taxa de câmbio (que já analisamos acima), salários, e preços das commodities. ${ }^{29}$ Não há evidências de modificações significativas nos salários. ${ }^{30}$

${ }^{28}$ Do contrário, teríamos de supor a improvável hipótese de que a expansão monetária de Ruy Barbosa foi destinada a elevar o padrão de vida dos segmentos de renda mais baixa. Segundo Franco (1989), o que há, na verdade, é um comportamento de desbancarização, ou seja, de manutenção da riqueza em ativos não-financeiros e em transações por fora da rede bancária.

29 Ver, a este respeito, Braga \& Bastos (2010), Braga \& Summa (2016) e Serrano (2010).

${ }^{30} \mathrm{Na}$ verdade, algumas categorias apresentaram aumento salarial no fim dos anos 1890, mas para repor as perdas inflacionárias ao longo da década, o que contrariaria a hipótese de reajustes salariais como autonomamente causadores de inflação: "A mão de obra da construção, exceto o servente de 
Em um período em que os trabalhadores ainda não se organizavam em sindicatos, seria pouco provável a ocorrência de reajustes sistemáticos dos salários capazes de provocar aceleração inflacionária.

Finalmente, a outra possibilidade de fonte de pressões inflacionárias seria 0 aumento dos preços internacionais das commodities ser repassado aos preços domésticos. ${ }^{31}$ Mas esses anos iniciais da década de 1890 coincidem, na verdade, com uma queda do preço das commodities - o Brasil foi afetado pela queda do preço do café, como já descrevemos anteriormente. Resta, assim, a desvalorização cambial como item do processo de formação de preços capaz de ter provocado a aceleração inflacionária desses anos em tela.

\section{Considerações Finais}

Quando estudada mais a fundo, a crise do Encilhamento parece ser mais um exemplo de episódio que, não obstante a ortodoxia tenha tentado atribuir a políticas econômicas supostamente mal conduzidas, na verdade possui uma origem mais profunda e frequentemente ignorada pela literatura. Conforme este trabalho buscou demonstrar, a sucessão de eventos que ocorreram no início da primeira década republicana possui uma incontestável influência do cenário externo, tendo em vista a vulnerabilidade que atingia os países periféricos inseridos no contexto internacional do padrão ouro libra.

Há fortes evidências que permitem uma compreensão da crise do Encilhamento em termos distintos do que sugere a ortodoxia. Eventos como a moratória argentina e a consequente quebra do banco inglês Baring Brothers provocaram fuga de capitais em massa e desvalorização do câmbio, gerando pressões sobre o nível de preços. A inflação foi, portanto, causada pela crise cambial, e não pelo papelismo de Ruy Barbosa e de seus antecessores. Se algo faltou à política monetária de Ruy Barbosa, pode-se dizer que foi uma presença maior do Estado, de forma a regular e fiscalizar as atividades das empresas criadas nesse período e também de gerar melhores expectativas para que a expansão

obras, e os operários não especializados das fábricas de sabão e velas (seções de embalagem, cartuchos e prensas) tiveram um aumento, enquanto que os mais especializados sofreram uma baixa. Os salários das outras categorias sócio profissionais apresentaram alta, exceto os do sacristão, andador, professor primário, porteiro e hortelão que diminuíram ligeiramente. Os salários que aumentaram mais proporcionalmente foram os de administrador de hospital e escriturário" (LOBO et al., 1973).

31 Isto porque, se não for possível vender a commodity no mercado doméstico por um preço mais elevado, o produtor preferirá vende-lo exclusivamente no mercado internacional, provocando desabastecimento no mercado interno. 
monetária pudesse se desdobrar em maiores investimentos produtivos (e não especulativos). De todo modo, conforme procuramos argumentar, os fatores externos tiveram um papel fundamental na deflagração da crise do chamado Encilhamento.

\section{REFERÊNCIAS}

BARBOSA, B. S. A Crise do Encilhamento. Niterói: UFF, 2009. (Dissertação de mestrado em economia na UFF).

BASTOS, P.P. Centro e periferia no padrão ouro-libra: Celso Furtado subestimou a dinâmica da dependência financeira? Texto para discussão n.138. Instituto de Economia da UNICAMP, 2008 (disponível em: http://anpec.org.br/revista/vol8/vol8n4p169 197.pdf).

BASTOS, P.P. Ortodoxia e heterodoxia antes e durante a era Vargas: contribuições para uma economia política da gestão macroeconômica nos anos 1930. Texto para discussão n.179. Instituto de Economia da UNICAMP, 2010 (disponível em: http://www.anpec.org.br/revista/vol9/vol9n4p183 214.pdf).

BOTELHO JR., C de O. Instabilidade Financeira na Primeira Década Republicana. Campinas: UNICAMP, 2002. (Dissertação de Mestrado em economia na UNICAMP).

BRAGA, J. \& BASTOS, C. P. M. Conflito Distributivo e Inflação no Brasil: uma aplicação ao período recente. In: VIANNA, S. T. W., BRUNO, M. A. P. \& MODENESI, A. M. (Org.)

Macroeconomia para o Desenvolvimento: crescimento, estabilidade e emprego. Perspectivas do Desenvolvimento Brasileiro, Livro 4. Brasília: Ipea, 2010.

BRAGA, J. M.; SUMMA, R. Estimação de um modelo desagregado de inflação de custo no Brasil. Ensaios FEE, Porto Alegre, v. 37, n. 2, pp. 399-430, set 2016.

CALÓGERAS, J. P. A política monetária do Brasil. São Paulo: Companhia Editora Nacional, 1960.

DELFIM NETTO, A. O problema do café no Brasil. São Paulo: IPE/USP, 1981.

EICHENGREEN, B. A globalização do capital: uma história do sistema monetário internacional. São Paulo, Editora 34, 2000.

FERRER, A. La economía argentina. Desde sus orígenes hasta principios del Siglo XXI. Buenos Aires: FCE, 2004.

FILOMENO, F. A. A Crise Baring e a Crise do Encilhamento nos quadros da economiamundo capitalista. Economia e Sociedade, Campinas, v. 19, n. 1, p. 135-171, 2010 (Disponível em: http://www.scielo.br/pdf/ecos/v19n1/a06v19n1).

FONSECA, P. C.; MOLLO, M. L. Metalistas x papelistas: origens teóricas e antecedentes do debate entre monetaristas e desenvolvimentistas. Belo Horizonte, Nova Economia, 2012 (disponível em: https://www.lume.ufrgs.br/handle/10183/94549).

FORD, A. Argentina y la Crisis de Baring de 1890. Revista de Economía y Estatística, Tercera Época, v. 13, n. 3-4: 3o y 4ํTrimestre, pp. 133-167, 1969 (disponível em: https://revistas.unc.edu.ar/index.php/REyE/article/viewFile/3664/5736). 
FRANCO, G. H. B. A primeira década republicana. In: ABREU, M. de P. (org.). A ordem do progresso: cem anos de política econômica republicana, 1889-1989. Rio de Janeiro:

Campus, 1989. p. 11-30.

FRANCO, G.H.B. Reforma Monetária e Instabilidade Durante a Transição republicana. Rio de Janeiro: BNDES, 1983.

FURTADO, C. Formação Econômica do Brasil. 34aa edição. São Paulo: Companhia das Letras: 2007. [1959].

IBGE. Estatísticas Históricas do Brasil. Rio de Janeiro, 1990.

LENZ, M. H. A Crise Argentina de 1890: Dívida e Instabilidade Externa. Análise

Econômica, Porto Alegre, v. 28, n.54, p.225-248, 2010 (disponível em:

https://seer.ufrgs.br/AnaliseEconomica/article/view/11875/11061).

LENZ, M. H. A evolução dos bancos argentinos no último quartel do século XIX: a influência dos bancos estrangeiros e a crise dos anos noventa. Ensaios FEE, Porto Alegre, v.22, n.2, p. 225-247, 2001 (disponível em:

https://revistas.fee.tche.br/index.php/ensaios/article/view/2008/2389).

LENZ, M. H. Crescimento econômico e crise na Argentina de 1870 a 1930: a Belle Époque. Porto Alegre: Editora da UFRGS/ Fundação de Economia e Estatística Sigfried Emanuel Heuser, 2004.

LENZ, M. H. Crise e negociações externas na Argentina no final do século XIX: o início da insustentabilidade do modelo aberto. Economia e Sociedade, Campinas, v. 15, n. 2, p. 375399, 2006 (disponível em:

https://periodicos.sbu.unicamp.br/ojs/index.php/ecos/article/view/8642913).

LENZ, M. H. O período de intenso crescimento econômico argentino de 1870 a 1930: uma discussão. História econômica \& história de empresas, VI. 2, 2003.

LOBO, E. et al. Estudo das categorias socioprofissionais, dos salários e do custo da alimentação no Rio de Janeiro de 1820 a 1930. Rio de Janeiro: Revista Brasileira de Economia, v.27, n. 4, p.129-176, 1973.

LUNA, F. V.; KLEIN, H. S. The Economic and Social History of Brazil since 1889. Cambridge: Cambridge University Press, 2014.

MENEGHETTI, C. B. A precariedade da administração monetária em um país periférico, sob as regras do padrão-ouro: Brasil, 1888-1900. Campinas: UNICAMP, 2006. (Dissertação de mestrado em economia pela UNICAMP)

PELÁEZ, C. M. As consequências econômicas da ortodoxia monetária, cambial e fiscal no Brasil entre 1889-1945. Revista Brasileira de Economia, Rio de Janeiro, v. 25, p. 5-82, 1971 (disponível em: http://bibliotecadigital.fgv.br/ojs/index.php/rbe/article/viewFile/59/6223).

PELÁEZ, C. M.; SUZIGAN, W. História Monetária do Brasil. Brasília: Editora Universidade de Brasília, 1981.

PEREIRA, B. R. Revisão crítica da hipótese de poupança forçada para a economia brasileira: 1946-1964. Niterói: UFF, 2006. (Dissertação de mestrado em economia na UFF).

PRADO, L. C. D. A Economia Política das Reformas Econômicas da Primeira Década Republicana. Análise Econômica n. 39, 2003 (disponível em: https://seer.ufrgs.br/AnaliseEconomica/article/viewFile/10724/6335). 
RAPOPORT, M. Historia económica, política y social de la Argentina (1880-2003). Buenos Aires: Emecé, 2013.

SCHULZ, J. A Crise Financeira da Abolição: 1875-1901. São Paulo: Editora da Universidade de São Paulo, 1996.

SERRANO, F. Juros, câmbio e o sistema de metas de inflação no Brasil. Revista de Economia Política, 30 (1), pp., 63-72, 2010.

TANNURI, L. A. O Encilhamento. São Paulo: Hucitec, 1981.

TAUNAY, V. de. O Encilhamento, Cenas contemporâneas da Bolsa de Valores do Rio de Janeiro em 1890, 1891 e 1892. Belo Horizonte: Itatiaia, 1971.

TRIFFIN, R. O Sistema Monetário Internacional. Rio de Janeiro: Expressão e Cultura, 1972.

TRINER, G.; WANDSCHNEIDER, K. The Baring Crisis and the Brazilian Encilhamento: An early example of contagion among emerging capital markets? Financial History Review 12.2, pp. 199-225, 2005.

VILLELA, A.; SUZIGAN, W. Política do governo e crescimento da economia brasileira: 1889-1945. Rio de Janeiro: IPEA/INPES, 1973.

\section{NOTAS DE AUTOR}

\section{CONTRIBUIÇÃO DE AUTORIA}

Lohana Monaco Bezerra - Concepção, coleta de dados, análise de dados, elaboração do manuscrito, participação ativa na discussão dos resultados, revisão.

Victor Leonardo Figueiredo Carvalho de Araújo - Concepção, análise de dados, elaboração do manuscrito, participação ativa na discussão dos resultados, revisão e aprovação da versão final do trabalho.

Fernando Augusto Mansor de Mattos - Concepção, análise de dados, participação ativa na discussão dos resultados, revisão e aprovação da versão final do trabalho.

\section{FINANCIAMENTO}

Não se aplica.

\section{CONSENTIMENTO DE USO DE IMAGEM}

Não se aplica.

\section{APROVAÇÃO DE COMITÊ DE ÉTICA EM PESQUISA \\ Não se aplica.}

\section{CONFLITO DE INTERESSES}

Não se aplica.

\section{LICENÇA DE USO}

Este artigo está licenciado sob a Licença Creative Commons CC-BY. Com essa licença você pode compartilhar, adaptar, criar para qualquer fim, desde que atribua a autoria da obra.

\section{HISTÓRICO}

Recebido em: 02-03-2020

Aprovado em: 20-03-2020 